\title{
Self-government Elements in Town-planning of the Russian Federation: Public Hearings Experience
}

\author{
Zinaida Ivanova ${ }^{1, *}$ \\ ${ }^{1}$ Moscow State University of Civil Engineering, Yaroslavskoe shosse, 26, Moscow, 129337, Russia
}

\begin{abstract}
The authors consider possibilities of public control of townplanning projects' approval by means of public hearings. They underline the significance of public hearings which enable clarifying the viewpoints of experts, citizens and formulating an efficient action plan with account of opinions of all the concerned parties. The article analyses Russian Legislation related to public hearings, notes disadvantages of legislation in terms of public hearings organization and breaches of hearing procedure basing on case studies of public hearings in Russian cities. The authors studied the experience of public hearings in the European countries. Using positive examples of public hearings organization in Denmark they formulated their proposals on optimization of this democratic institution in Russia. The authors also demonstrate the need for sociological research to assess the effectiveness of urban planning decisions and activities of the municipal authorities in the field of creating a comfortable environment.
\end{abstract}

\section{Introduction}

Public hearings are one of the means of direct participation of population in solution of state and local-level issues. Public hearings is a complex legal institute promoting implementation of democracy principles in administrative activity of state and municipal bodies, promoting transparency of the solutions, they allow citizens influence the development of these solutions.

Theoretical development of the issue of public hearings had begun in the 90 s of the XX century. Public participation in decision-making process was analyzed in investigations and the experience of public hearings organization in different issues was summarized, such as: telecommunication issues [1], health promotion and health education [2], use of genetically modified food [3] and other. Manuals on consensus conferences were created, which stated guidelines for conferences organization, characteristics of the stages, rules of organization and venue, information distribution [4]. The majority of investigations were dedicated to study and description of the experience of Denmark, because in the 1980s of the 20th century the model of consensus conference had been developed in Denmark. This model has been implemented in other European countries. In particular a work of F. Seifert [5] is dedicated to this model implementation in Austria, an article of A. Ricroch and F. Jésus [6]

\footnotetext{
*Corresponding author: ivanovazi@mail.ru
} 
- in France. A work ofS. Ureta[7] analyses of a failed attempt to implement the Danish experience of holding conferences.

The term "public hearings" has appeared in Russian Federation in 2003 and it has been related to the development and adoption of the Federal Law no. 131-FZ from 06.10.2003 "On general principles of local self-government organization in the RF" for passing regulatory acts with participation of the community(incentivized community). Some researchers believe that public hearings are a form of deliberative democracy on a municipal level (A. V. Sigarev) [8]. Such a democracy (discussion democracy or consulting democracy) takes intermediate position between direct and representative democracy. Also "public hearings" are regarded as a constitutional-legal institution, as a form of direct democracy (S.S.Zenin, M.A.Ochertine), efficiency of which increases on the local level of governance $[9,10]$

In different countries different social technologies of holding public hearings have been developed. Several close approaches are united under a general name "Civil conferences":

- Citizens' Jury - a variant developed in the USA;

- Consensus Conferences - a European variant developed in Denmark and widely used in European countries;

- Public hearings (a variant developed and used in Russia).

In Russia Federal Law no. 212-fz from July 21, 2014 establishes the right of citizens to participate in decision elaboration, public control of the activity of governmental authorities, local government bodies, state and municipal organizations.

Public control may result in: well-prepared outcome document of public control results sent to governmental authorities: final document of public monitoring, public inspection certificate, opinion public examination, report of public debate, report of hearings.

According to the Town-Planning Code of the Russian Federation, urban residents have the right and the opportunity to participate in the discussion of urban planning projects and to express their needs through public hearings. However their practical implementation is hardly effective. The legislation governing public hearings is insufficiently elaborated; therefore, their results are not obligatory for decision-making municipal authorities. Nonetheless, various concerns, expressed by the residents of particular communities and districts, cause hundreds and even thousands proposals and comments on their behalf in the process of public hearings, which are not binding. The institution of public hearings needs consistent regulatory support, including a consistent legislation governing their organization and implementation, the status of their participants, and provisions on/procedures for their regard by the public authorities in the process of decision making. New electronic and face-to-face formats of public hearings must develop. In particular, it is possible to use crowd sourcing mechanisms. It will help to solve many problems: the creation of the product (content), the vote and the search for solutions, information gathering and collecting opinions.

\section{Materials and Methods}

A modernization of public hearings is cross-disciplinary sphere and encompasses the most recent developments in various areas of knowledge (psychology, sociology, law, political science, culture studies, and management). Public hearings require the improvement of the legislation/the enforcement mechanism; foster the involvement of the civil society in urban management. Improvement of the procedure of public hearings and regard for the residents' opinions in the decision making process develop into an integrated action designated to solve social, legal, political, and cultural problems.

Sociologists are actively involved in the discussion of public hearings organization, search for efficient opinion-accounting instruments of citizens. A leading research worker 
of the Institute of Sociology of the Russian Academy of Sciences (ISRAS)E.M. Akimkin has held case studies of the first public hearings in Moscow in correspondence with the Town-Planning Code and has noted the disadvantages in their organization procedure [11]. Also research workers of the ISRASI. Shcherbakova and Z. Zaripova analyzed a public hearings procedure on approval of a planning design in the end of 2010 in one of Moscow regions [12]. The authors noted draw-backs existing in public hearings organization.

The issues of communication space organization in the Internet are investigated in the Center of Management Sociology and Social Technologies of the ISRASand its Laboratory of Info social Technologies Investigation, which gives opportunities for public hearings organization in the Internet using crowd sourcing. In general there is lack of scientific researches on public hearings in Russia.

The authors used document analysis technique in their investigation. Materials on public hearings on town-planning projects, land use and property management plans in Russian cities have been analyzed. In particular public hearing materials on town-planning projects in Moscow, Saratov, Kirov, Kaliningrad and Nizhny Novgorod have been analyzed.

\section{Results}

The Town-Planning Code of the RF affords citizens the right and possibility to participate in urban development planning by public hearings. Such hearings are obligatory in the development of general layouts, land-use and construction recommendations and development plans. The Town-Planning Code of the RF states "Public hearings with participation of residents of settlements, city districts on general layouts, including making amendments in them, are obligatory for enforcement of rights of a human for safe living environment, rights and legitimate interests of land and capital construction projects proprietors"[13].

Public hearings are being held in each settlement of a municipal formation. Favorable conditions are created during the hearings for equal possibilities of all the individuals involved for expression of their opinion [13]. This article is enhanced and enforced by legal norms of other articles of the Town-Planning Code of the RF, in particular by articles 23, $24,25,37,39$. Especially in is closely related with article 24 "Preparation and Approval of General Layout of a Settlement, General Layout of a City District".

Though unfortunately the law doesn't fix the binding nature of accounting for the results of public hearings. The head of local administration takes a decision basing on the conclusion of public hearings: 1) whether to approve a general layout project and send it to representative body of a municipal formation or 2) whether to decline it and send it for revision. The head is not obliged to take account of the opinions of public hearings' participants. As the Russian sociologist E.M. Akimkin notes, the decision-making process and account for citizens' opinions are not fixed in law. For example, "A district committee affiliated to Moscow government for urban development, land use and construction only record public hearings results, but doesn't analyze them. Then it transfers the records to the government, which is free in respect of the citizens 'opinion [11].

The chief architect of Moscow S. Kuznetsov suggested doing without public hearings when solving issues related to large-scale town-planning projects. Though independent municipal officials claimed to preserve public hearings in Moscow. Some elected officials expressed surprise and indignation that the authority of Moscow municipal elected officials is reduced in comparison with the authority of local government in other cities of Russia. They insisted on bringing Moscow legislation into compliance with Federal legislation, firstly concerning the issues of local self-government[14]. 
On December 16, 2015 the Moscow parliament adopted the Law of the City of Moscow "On Amendments to the Law of Moscow from June 25, 2008 № 28" Town Planning Code of the City of Moscow". The adoption of the law is due to the need to bring the provisions of the Town Planning Code of the City of Moscow in compliance with federal law, in which more than 70 amendments have been made over the past few years. It will optimize the process of public hearings in Moscow and will contribute to a more dynamic implementation of major urban development projects in the city[15].

Despite the adopted amendments, the Russian researchers note that "in general the official procedure of citizens' participation in town-planning today looks more like sophisticated tactical play of opposing forces, than an attempt to find mutually acceptable solution" [16]. Usually hundreds or even thousands (if concerning important issues) of suggestions and comments of citizens are gathered, though they carry no legal weight. "The law (Town-Planning Code of Russia) acknowledges the right to express opinions and suggestions. But it doesn't bind to take them into account - there are no procedures and necessary regulations for it. An opinion expressed by a society of citizens carry no legal weight [13].

Well-organized public hearings give possibility to take into account the opinions of all the participants, to develop an efficient action plan with account for all the concerned parties. Though often public hearings are accompanied by conflicts and debates. The reality paves the way to a variety of contradictory interests. It's difficult for different social groups and communities to obtain consensus. The passions are rising especially when there is lack of information, under governmental pressure, breach of the procedure [17]. Any breaches of democratic procedures of town-planning projects' consideration, including public hearings procedures, are the favorite topic of critical speeches of political opposition forces which also escalates the situation [18].

\section{Discussion}

We can see three main reasons of public hearings' inefficiency, which have cause and effect relationship:

1. Disinterestedness of the administration, city government, project organizations, developers in citizen's participation in discussion and decision-making on a project. Enthusiastic citizens usually prevent the mentioned organizations and individuals from exclusive disposal of land and town property.

2. Lack of careful legal consideration of the issue, lack of articles on compulsory account for the opinions of public control agencies.

3. Inertia and inactivity of citizens, who made sure more than a few times that it is waste of time and energy to fight for consideration of their opinions. We can mention here the absence of the tradition of active involvement in decision-making and immaturity of civil society in Russia, which would control the actions of the government and would not let corruptive possession of town property.

These factors together bring to naught democratic institutes and forms of public control. The government, business and designers working for them are not interested in the population having correct idea of a project, of its implementation and its results (influence on other aspects of citizens' life). Also not all the projects can be discussed by citizens. In particular there should be no hearings when preparing area planning schemes. A territory for domestic solid waste deposit may be allotted without hearings. Industrial sites or other technical objects effecting the environment are beyond the competence of regional administration and autonomous public bodies. No matter how indignant citizens are, they can do nothing [16]. 
The process of town-planning project preparation is characterized by absence of social studies. Usually it is impossible to learn anything about social situation, public moods, troubles and needs in design areas from the materials proposed for public hearings [19, 20].

For comparison we would like to give examples on public hearings procedure in Denmark. An idea of citizen's access to participation in decision-making of governmental bodies and local self-government is the conceptual basis of public participation procedures [21]. For example, the Danish system of assessment of the effect on the environment is applied to the projects which are likely to influence the environment greatly [22]. The influence of a project on people, flora, fauna, soil, water, air, climatic factors, architectural and archeological heritage and landscape should be estimated before the project implementation. A governmental body organizes public hearings two times in order to apply the opinion and knowledge of citizens. The aim is to minimize mistakes during the work over project which may cause negative effect. The hearings consist of two stages, 8 weeks for each stage. The first public hearings are held on the initial state of a project, the second - on the stage when the project may be presented as a final report. On the first stage a consumer prepares a booklet presenting a project and possible ecological problems and a plan of public hearings. The materials are to be published in the Internet and in a library for public hearings. Responds and alternative variants of the society are applied for making changes in the project. On the second stage a report is discussed, which is distributed via Internet and library for public hearings. According to comments it is checked whether all the rational proposals are included into the project and whether it is necessary to make some more changes for final approval. All the approved documents in their final version are also posted in the Internet [22].

Such good practices of public hearings when account for citizen's opinion is obligatory and citizens feel their responsibility for the final project on territory planning should be investigated by state departments' representatives, local authorities and citizens [23].

\section{Conclusions}

1. It is necessary to improve legal avenues of population participation in predevelopment investigations in the field of urban development, on project implementation stage and on post-design stage. Legal backing of the hearings procedure is obligatory on all the stages of project approval and implementation.

The State Committee for Construction of the Russian Federation presented recommended practices for the procedure development of citizens' participation in discussion and decision-making on the construction issues and issues on the use of city and other settlements' territory, but it is not enough to make public hearings an operating institute [24].

2. The development of social devices is necessary (interaction of different social structures, institutes, developed norms, forms of citizens' participation, etc.), which would provide efficient functioning of public hearings institute.

3. Arranging ways of systematic awareness of citizens with a project development, with the implementation procedure, post-design processes via Internet, advertisements and notifications, meetings of urban planners, architects, designers, members of urban development departments with citizens. It is necessary to provide publicity not only after, but also in the process of design.

4. Application of crowd-sourcing mechanisms via Internet technologies. Crowd sourcing will allow solving many tasks: creation of the content, voting, searching for the solution, gathering information and opinions. The possibility to address hundreds of thousands of people for their feedback in the form of opinions, detachment of the target group of consumers is the absolute advantage of crowd sourcing. 
5. Development of incentive system for citizens and attraction of different city communities to discussion of the issues of city development and concrete project implementation. Lack of attention is paid to the modern processes of city social structure changes, appearance of new societies such as migrants, online communities, and artistic subcultures.

6. Promotion of forecast investigations, study of new tendencies in the development of a postindustrial city, study of the experience, problems of the cities of the world. Which communities are most active in modern cities? Which technological platforms and solutions they use for communication? Such issues had been discussed on Moscow Urban Forum 2016. In the section "Active Metropolis. Visible and invisible urban communities" the discussion focused on the search of answers to the questions: what consequences for city life are already visible and what consequences may be forecasted in the future due to the explosive growth of variety and quantity of city communities? [25]

7. Development of sociological and diagnostic studies in the field of urban development for investigation of citizens' needs their attitude to a proposed project and public hearings procedure [26]. "The necessity of opinion polls within the given subject is also determined by the requirements of studying the people's confidence in the local authorities. The level of trust of people in various government bodies and the degree of satisfaction with their activity is an important thing not only for the stability of the authorities, its legitimacy, but also for the effectiveness of its activity. Without the positive mood of people in relation towards the authorities, it is impossible to solve social problems at any level, to say nothing of building the social state" [27].

8. Organization of citizens' awareness applying best public hearings practices, successful experience of other countries where public hearings is an efficient operating tool of citizens' participation in administration.

Therefore we can make a conclusion that the issue of reforming public hearings procedure, improving legislation in this field should become an object of regard for governmental agencies, local government authorities, lawyers and scientists.

\section{Acknowledgements}

This study was conducted with the support of the project Erasmus + Jean Monnet "Intercultural Europe: Urban Planning Based on the Principles of Social Integration" (IEUP), funded by the European Commission. The conclusions and opinions presented in this document reflect the viewpoint of the authors only, and the Commission will not bear responsibility for any use of the information contained therein.

\section{References}

1. URL: http://www.geography.dur.ac.uk/documents/lmc/Guston\%20$\%$ 20evaluating\%20the \%20First $\% 20$ US\%20consensus\%20conference.pdf.

2. J. P. Allegrante, M. M. Barry, C. O. Airhihenbuwa, M. E.Auld, J. L. Collins, MC.Lamarre, et al., Health, Educ.Behav, 36, 476-482 (2009)

3. URL: http://www.oecd.org/dataoecd/53/56/2537449.pdf.

4. A.P. Nielsen et al., Consensus Conference Manual (LEI, The Hague, February 2006)

5. F. Seifert, Public Understanding of Science, 15(1),73-88 (2006).

6. A. Ricroch and F. Jésus, Public Understanding of Science 18 (1), 91-102 (2009)

7. S. Ureta, Public Understanding of Science, 1(25) 499-511 (2016)

8. A.V. Sigarev, Russian Justice, 4, 70-72 (2012) 
9. S.S. Zenin, State authority and local self-government, 3, 29 - 31 (2012)

10. M.A. Ocheretina, Constitutional and municipal law, 23, $22-25$ (2008)

11. URL: http://www.ssa-rss.ru/files/File/congress2012/part36.pdf.

12. I. Shcherbakova, Z. Zaripova, The Authority, 9, 118-120 (2012)

13. Town-Planning Code of the Russian Federation No 190-FZ(29.12.2004)

14. URL: https://www.gazeta.ru/social/news/2013/01/15/n_2707657.shtml.

15. http://dgp.mos.ru/presscenter/news/detail/2463934.html

16. URL: http://www.gkh.ru/article/85280-publichnye-slushaniya-v-sferegradostroitelnogo-planirovaniya-novyy-format-

17. I.P. Pryadko, International Journal of Applied Engineering Research, 10(21) 4214742152 (2015)

18. Andreev I.V., Integration, partnership and innovations in construction science and education (MGSU Publ., Moscow, 2015)

19. I. P. Pryadko, A. D. Ishkov, Economy and Entrepreneurship, 9 (74), 997-1001 (2016)

20. L. V. Vlasenko, Economy and Entrepreneurship, 8, 545-548 (2016)

21. URL: http://participedia.net/en/methods/participatory-consensus-conferences

22. URL: http://ecom.su/technologies_materials/index.php?id $=472$

23. N.G. Miloradova, A. D. Ishkov, Procedia Engineering, 117, 246-251 (2015)

24. Russian Standard MDS 15-1.99

25. URL: http://mosurbanforum.ru/program

26. Z.I. Ivanova, O.V. Yudenkova, Applied Mechanics and Materials, 737, 909-912(2015)

27. Z.I. Ivanova, T.N. Golomazova, Stroitel'stvo: nauka I obrazovanie 1 (2014). URL: http://www.nso-journal.ru/public/journals/1/issues/2014/01/6_Ivanova.pdf 